\title{
A property rights-based analysis of the illegal logging for fuelwood in Kosovo
}

\section{Laura Bouriaud $^{a, *}$, Liviu Nichiforel ${ }^{a}$, Lina Nunes ${ }^{b}$, Helena Pereira ${ }^{c}$, Agron Bajraktari ${ }^{d}$}

a University "Stefan cel Mare”, Str. Universitatii, Nr. 13, 720229 Suceava, Romania

b National Laboratory for Civil Engineering, Lisbon, Portugal

c Technical University of Lisbon, School of Agronomy, Portugal

${ }^{\mathrm{d}}$ University of Prishtina, Faculty of Applied Sciences, Republic of Kosovo

\section{A R T I C L E I N F O}

Article history:

Received 17 December 2013

Received in revised form

28 May 2014

Accepted 30 May 2014

Available online

Keywords:

Fuelwood

Illegal logging

Property rights

Enforcement mechanisms

Kosovo

\begin{abstract}
A B S T R A C T
The increased demand for fuelwood may have the side-effect of unsustainable use of forest resource. The case of Kosovo fuelwood production is of a peculiar relevance to studying the drivers of the unsustainable patterns of forest biomass use in a post-war and poor economic context. The domestic market demand for fuelwood in Kosovo is estimated at more than $1.5 \mathrm{hm}^{3}$, while the legal supply, including imports, is slightly higher than $0.3 \mathrm{hm}^{3}$. Illegal logging for satisfying Kosovo population fuelwood needs is therefore widespread. The annual illegal fuelwood harvesting represents a market of up to 21.6 million euro and is done mostly by well organised groups of individuals, with market-oriented behaviour, acting rather in State than in private forests. After identifying the drivers of illegal logging for fuelwood, the paper provides an analysis of fuelwood extraction in relation with property rights distribution, structured along two lines: a) which was the evolution of the management and exclusion rights over the forest resource during the latest decades; $b$ ) which are the current enforcement mechanisms of the property rights and how are they performing. The paper describes a decades-long history of mismatching economic property rights arrangements. Thus, the dispute between the central agency and municipalities in performing exclusion rights on timber extraction definitely weakened the Kosovo system of law enforcement. Currently, the enforcement mechanism proved to be unhelpful in controlling illegal logging. As result, most of the Kosovo fuelwood production is based on an de facto open-access regime.
\end{abstract}

๑) 2014 Elsevier Ltd. All rights reserved.

\section{Introduction}

Forests in Kosovo cover $42 \%$ of the country and harbour the potential to supply biomass for energy purposes. The high density of the Kosovo population (175-220 inhabitants per $\mathrm{km}^{2}$ ) and the large proportion of the population living in rural areas, e.g. 61\% according to Population Census from 2011 [1] put a high pressure on forest resource. From this point of view, Kosovo needs to implement effective and coordinated forest management policies, and to promote a more efficient use of fuelwood [2]. The sustainable use of the forest resource

\footnotetext{
* Corresponding author. Tel.: +40 (0) 741101174; fax: +40 (0) 230520080.

E-mail addresses: bouriaud@usv.ro, bouriaud@gmail.com (L. Bouriaud). http://dx.doi.org/10.1016/j.biombioe.2014.05.028
}

0961-9534/@ 2014 Elsevier Ltd. All rights reserved. 
faces important challenges in both State and private properties, reflected in the way the rules for forest management are implemented and enforced.

Fuelwood represents $20 \%$ of the total of Kosovo's energy consumption [2]. The residential sector is the main consumer of fuelwood $(50 \%)$, followed by the service sector $(25 \%)$, industry (15\%) and agriculture (10\%) [2]. Of the total Kosovo forest area that is 481,000 ha, public forestlands represent $62 \%$ with a standing volume of $33.5 \mathrm{hm}^{3}$ versus $19.5 \mathrm{hm}^{3}$ (million cubic metre) in private forests [3]. A number of 120,000 forest owners shares 180,800 ha, that is an average private ownership of 1.5 ha split in 2.4 parcels [3]. Coppice forest dominates the forest area with $84 \%$. As a result of intensive cuttings, $58 \%$ of the public forest and $81 \%$ of the private forest are less than 60 years old [4]. The national forest inventory from 2002 estimated the annual allowable cut around $0.9 \mathrm{hm}^{3}$ gross, of which $55 \%$ is fuelwood [5]. However, in the past decade, the annual allowable cut calculated and legally available for harvesting through the current system of forest management planning was under $0.2 \mathrm{hm}^{3}$ [6].

The case of Kosovo fuelwood production is of a peculiar relevance to studying the drivers of the unsustainable patterns of forest biomass use in a post-war and poor economic context. A property-rights-based approach is used to complete and refine the standard explanation of illegal logging as policy failures in terms of law enforcement [7-9]. Although the issue of resource depletion and weak enforcement is quite well documented (see 152 cases in nine countries synthetized by Chhatre and Agrawal [9], there are no studies addressing the fuelwood overharvesting and weak law enforcement in European institutional context. The drivers of illegal logging, important from the perspective of designing appropriate policies, are not well documented either [10], few studies have been made in post-socialist countries [11,12], however theft in general is well addressed by the literature on the criminal enforcement [13-16]. Following a comprehensive analysis of property rights regimes by Kissling-Näf and Bisang [17], the study was structured along two lines: a) the property rights over the forest resource and the possibility of exclusion from the consumption of fuelwood; b) the enforcement mechanisms of the property rights. The study aims to identify how the property rights on forestland and timber (stock and flow) were established, policed and enforced in the latest decades in Kosovo to assess the impact of the economic rights delineation on the legality of fuelwood production and trade.

\section{The challenges of the fuelwood sustainable production}

Sustainable fuelwood production challenges in Kosovo are: the changing institutional context, the degradation of the resource, the high amount of illegal logging and the extremely unbalanced ratio between the demand and supply.

In the last decade, Kosovo has attracted the attention of international donors supporting sustainable development of the forest sector. A forest strategy was adopted in 2009 and a new forest law is under debate (March, 2014). The Kosovo public authority for forests is the Ministry of Agriculture, Forestry and Rural Development. The management of public forests and the law enforcement in private forests are performed jointly by a central agency with six regional offices and by the municipalities (in number of 30). Forest inspectors, untrusted with control of law implementation, are currently acting within the central agency. Though the changes in the institutional settings for the natural resources have happened everywhere in countries in transition, in Kosovo they occurred in the particular context of war (1999), of United Nations Interim Administration Mission in Kosovo (UNMIK) (after 1999) and new Kosovo State establishment (2008) with first democratic elections and therefore first sovereign government in late 2010.

The war and post-war disorders led to a large degradation of the forests by logging, fire and illegal hunting [18-20]. While the coniferous forests are put at risk due to fire, bark beetles, or a lack of the thinning operations, the coppice forests suffer from heavy harvesting in some locations and from a lack of management interventions in some other locations [3]. Only about one-third of the forest area is considered ecologically healthy and economically productive and most of the remaining forests consist of immature trees and bushy low forests that are cut periodically for fuelwood [21].

Illegal logging is connected with forestry activities such as wood harvesting, processing, transporting and trading in violation of the law [22]. Different estimations exist on the amount of the illegally cut fuelwood. The studies available $[23,24,4-6]$ depict a situation unique in Europe. For example, the ratio between the legal and illegal logging is at least 1:1, but it might also be 1:5. The average annual value of the damages due to illegal activities was estimated at 1.5 million euro [24], while $40 \%$ of the public forests and $30 \%$ of the private forests are affected by illegal logging [6,3]. The latest national forestry inventory [25] assessed that over $90 \%$ of the annual fellings do not comply with the rules of law. Moreover, during the period 2002-2012 the annual harvesting has been $1.6 \mathrm{hm}^{3}$ compared with $1.45 \mathrm{hm}^{3}$ recommended as sustainable annual harvest [25] and compared with less than $0.2 \mathrm{hm}^{3}$ officially approved as annual allowable cut. One may estimate therefore that annual illegal logging amounted to $1.25 \mathrm{hm}^{3}$ during the period 2002-2012.

In the absence of more reliable data, and taking into account the share of fuelwood in the total primary wood production that is 55\% [25], the demand for fuelwood is used as a proxy for illegal harvesting. Before the war, the population was supplied with additional fuelwood from imports, and alternative sources of energy (e.g. coal) were available. During the 1999 war and in the post-war period, the economic difficulties of households, the insufficient energy (oil, gasoline) supply and the shortage of many other materials pushed the population to turn to a more intensive use of the fuelwood for house heating and cooking.

For example, some $50 \%$ of the 168,000 Kosovo families need fuelwood regularly and their demand is estimated in one study at $0.8 \mathrm{hm}^{3}$ [26] and at $1.5 \mathrm{hm}^{3}$ in two other studies from 2011 to 2013 [27,28]. Fuelwood is used by 85\% of urban households and by $100 \%$ of rural households, with an average consumption of $9.6 \mathrm{~m}^{3}$ per year [29]. Thus the annual domestic consumption of Kosovo households would range between 2.4 and $2.9 \mathrm{hm}^{3}$ stacked wood [29] or 1.56 to $1.88 \mathrm{hm}^{3}$ solid wood [30]. Therefore, if compared with the legal wood removal, the 
sustainability of fuelwood production faces the challenge of an extremely unbalanced ratio between the demand and the supply. Hajredini and Kampen [30] have estimated the gap between the demand and the supply of fuelwood at $1.27 \mathrm{hm}^{3}$ solid wood. For an average fuelwood price of 30 euro per cubic meter and an annual demand comprised between $0.55 \mathrm{hm}^{3}$ [6] and $1.2 \mathrm{hm}^{3}[25,30]$, illegal cut fuelwood represents a market of 9.9-21.6 million euro (Table 1), rather huge when compared with the total income of the forest agency, based on less than $0.2 \mathrm{hm}^{3}$ annual sales.

\section{Theoretical frame}

\subsection{Economic and legal property rights}

From the viewpoint of the sustainable use of a natural resource, property rights could be useful for society, only if they could be policed easily [31]. The role of the State is to define (legislative function of the State), interpret (judicial function of the State) and enforce (police function) the property rights [32]. Understanding the regime of timber harvesting requires analysing the specific combination of the ownership structure, the user rights of different actor groups and the extent of the State interventions in the management of the resource $[17,33,34]$, particularly in the case of former socialist countries [35] where important changes have affected the economic and legal property rights structure.

Politics and statutory rule-making [36] defines the rights structure. In the countries in transition, the legal rights were defined within the scope of the land reform policies. In contrast, the economic rights [37], e.g. the ability of the forest owner to enjoy the benefits of the resource, were defined in sector-based policies [38-40].

There is always a gap between the legal and economic rights, due to the measurement costs of unspecified attributes, the attempts to capture the benefits associated with the rights and the institutions that constraint the capture [41] or competition for the use of forests (i.e. who the other claimants for forest utilization are), the possibility of exclusion and the enforcement mechanisms [42,37]. The institutional context determines the ability of the owners and managers to forcefully maintain exclusivity of the rights [43]. The weak support of the institutions against trespassers "encourages opportunism, by increasing the relative payoffs from illegitimate versus legitimate activity" [35].

\subsection{Enforcement of the property rights in forestry}

Any structure of property relations requires a commitment from the recognized system of authority that will collectively enforce it $[37,44]$. Individuals who hold the exclusion rights have the authority to set up the qualifications to be met in order to have access to a resource [42]. This may be in the form of timber harvesting permits, rules for marking trees, issuing wood transportation documents, issuing administrative fines in case of minor law infringements and charging in Courts major law infringements, e.g. timber theft.

The enforcement of the property rights is performed in the forest sector by specific management structures hiring forest guards and by the forest inspection services. The forest guards are responsible for monitoring the forest activities and protecting forests against timber theft. The forest inspection services are in charge of limiting theft from state-owned forests and ensuring that private forests are effectively managed [45]. While forest guards are mainly liable toward the forest owners, forest inspectors represent the State authority and perform civil servant duties, yet their tasks are similar to those of a "forest police". The role of inspectors as public agents is to ensure public enforcement by detecting and sanctioning violators of legal rules [14].

\subsection{Conceptual framework of the property rights analysis}

A conceptual model of the impact of the property rights regime on natural resource management should avoid several methodological biases, due to, inter alia, the diversity of property rights regimes and of the State role [46]; the fact that property rights structure is strongly dependent on context and on the attributes of resource [41]; the fact that property rights require normative judgements about the distribution of the benefits in a society [44] and therefore property analysis is often, yet not recognized, ideologically driven $[47,48]$. To eliminate some of these biases, the study uses the analytical framework developed by Schlager and Ostrom [42] clarifying the position of the users according to the bundle of rights they hold (Table 2). Two collective-level rights [42] are essential in relation with enforcement: 1 ) the management right, such as

\begin{tabular}{|c|c|c|c|}
\hline Sources: & & $\begin{array}{l}\text { Harou and } \\
\text { Hajredini [6] }\end{array}$ & $\begin{array}{l}\text { Tomter et al.; } \\
\text { Hajredini and } \\
\text { Kampen }[25,30]\end{array}$ \\
\hline Estimation of the total illegal logging for fuelwood in Kosovo & $\mathrm{hm}^{3}$ & 0.55 & 1.2 \\
\hline From which, market-driven illegal logging of fuelwood $\left(60 \%^{\mathrm{a}}\right)$ & $\mathrm{hm}^{3}$ & 0.33 & 0.72 \\
\hline $\begin{array}{l}\text { Illegal fuelwood value in } € \text { (local price: haulage cost, } \\
\text { transportation cost, profit margin): } 15 € \mathrm{~m}^{-3}\end{array}$ & $M €$ & 4.95 & 10.8 \\
\hline $\begin{array}{l}\text { Illegal fuelwood value at the average market price } \\
\text { in } € \text { (sold in the cities): } 30 € \mathrm{~m}^{-3}\end{array}$ & $M €$ & 9.9 & 21.6 \\
\hline $\begin{array}{l}\text { Owners' losses - Damage value in } € \text { for stolen fuelwood } \\
\text { (calculated according to the Courts procedures): } 40 € \mathrm{~m}^{-3}\end{array}$ & $M €$ & 13.2 & 28.8 \\
\hline
\end{tabular}


Table 2 - The bundles of rights associated with position (Schlager and Ostrom, [42]).

\begin{tabular}{lccccc} 
& Owner & Proprietor & Claimant & Authorised user & $\begin{array}{r}\text { Unauthorised user } \\
\text { (e.g. illegal loggers) }\end{array}$ \\
\hline Access & $\mathrm{X}$ & $\mathrm{X}$ & $\mathrm{X}$ & $\mathrm{X}$ & $\mathrm{X}$ \\
Withdrawal & $\mathrm{X}$ & $\mathrm{X}$ & $\mathrm{X}$ & $\mathrm{X}$ & \\
Management & $\mathrm{X}$ & $\mathrm{X}$ & $\mathrm{X}$ & \\
Exclusion & $\mathrm{X}$ & $\mathrm{X}$ & & \\
Alienation & $\mathrm{X}$ & & & \\
\hline
\end{tabular}

the right to regulate internal use patterns and transform the resource and 2) the exclusion right, such as the right to determine who will have access and withdrawal rights and how those rights may be transferred. The owner has all the five categories of rights, while the "proprietor" does not have the right to alienate.

The study focuses only on a part of the forest resource, e.g. the property rights on forestland and timber, because they are fully specified and, theoretically, easy to police, as compared to many other forest attributes.

\section{Method of the study and data collection}

The empirical data are based on two categories of sources. Historical data upon forest resource utilization in Kosovo in the last five decades, available in different studies and documents, forest management plans and the forest laws and regulations are combined with a sociological enquiry [49]. The evolution of the property rights in forest sector and their impact on timber extraction were assessed via interviews. The absence of available and reliable data imposes a two stages approach of the data collection and a careful selection of interviewed people, in order to ensure, as much as possible, a non-biased interpretation of the illegal logging phenomenon. In a first stage, 31 interviews were conducted with representatives of the central government: public servants from the forest department from the ministry (7 people), forest officials from the main forest agency (9 people) and from forest inspector department ( 5 people), officials from other ministries (justice, domestic affairs) (4 people), representatives of the association of town councils and of forest owners (4 people), and representative of forest industry ( 2 people). In a second stage, seven amongst the 30 Kosovo town councils were selected as case studies, based on the characteristics of the forest resource and the extent of the illegal logging within their territorial limits. At the municipality level, 17 interviews were held with forest directors (7), forest technicians (7), major (1) and local councils representatives (2). The interviews were structured openly along two main axes: one narrative, allowing the people interviewed to communicate their own perceptions about the situation of forest harvesting and illegal logging in Kosovo, before and after the war, and one explanatory [49], placing the interviewed people in the situation to identify and explain which are the factors of success or failure in protecting Kosovo forests against illegal logging. In total 48 interviews were held between December 2010 and December 2011, with an average duration of $50 \mathrm{~min}$. Two workshops at the central level (5 and 10 participants) and two at the municipality level (8 and 7 participants) were organized with the aim to validate some preliminary results, e.g. the drivers of illegal logging in Kosovo and its extent.

Data analysis is based on the qualitative content analysis method. This procedure is rooted in the thematic codification method, which identifies the differences and similarities/ commonalities between the actors in the target population in relation to specific research items [50].

\section{Results and Discussion}

\subsection{The drivers of fuelwood illegal logging}

The interviews and the organization of the workshops have allowed the identification of three main drivers of illegal logging:

1. Poverty-driven illegal logging (illegal logging for subsistence) appears when poor people steal a few cubic meters directly from forests (without any intermediary) because they cannot afford (to buy) it. This form of illegal logging does not represent more than $10 \%$ of the total amount of illegally cut timber (Interviews 2, 7, 32). One must notice that the Kosovo State is supplying fuelwood for free to poor social categories, seven to ten cubic meters per year and per family;

2. Illegal logging done by the forest owners themselves (irregular or unauthorised cutting) happens when the forest owners extract fuelwood without the required official forms (e.g. harvesting permits). This form of illegal logging is widespread in private forests, and it may represent $10 \%-$ $30 \%$ of the total amount of illegally cut timber (Interviews 2 , 7, 32). Partly, the irregular cutting is explained by the long and bureaucratic official approval process or by the absence of ownership title that is required for obtaining a harvesting authorisation (Interview 5, 6, 7, 14);

3. Market-driven illegal logging is responsible for most of the illegal fuelwood logging in Kosovo. Between 60 and $80 \%$ of the illegal logging operations are driven by profit-seeking activities with a view to meeting the fuelwood market demand (Interviews 2, 3, 4, 7, 10, 32). Market-driven illegal logging covers two forms: organized crime that is organised timber theft and illegal timber business that is overharvesting. The same people can undertake both forms of illegal logging, according to the existing opportunities.

The illegal loggers are family or small size enterprise-like organised and they are part of the local community. They use several strategies to get access to the resource. They may buy several tracts at once, for covering further illegal harvesting 
activities. For example, they will cut trees from tracts other than what they bought, preferably State or absentee owners (Interview 4, 5), which classifies their actions as timber theft. In the bought tracts, the loggers may also cut and trade larger quantities than allowed (Interview 5), which classifies as overharvesting. As described in an interview, the incentives for theft or overharvesting are high: "for 10000 euro paid in the tendering process, the logger has a return up to 10 times higher. From the $20 \mathrm{~m}^{3}$ loaded in the truck, only seven or eight are legally cut. Two or three truckloads per day are transported with the same document of origin. A car travels in the front of the truck to detect whether the police is controlling the road traffic or not" (Interview 6). A town council representative asserted that in these situations "the loggers got accustomed to going into the forests as in their own property" (Interview 6).

The well-organized traffic and trade of fuelwood enhance huge opportunities for corruption (Interviews 2, 3, 4, 9, 10). Illegal harvesting for trading purposes requires a "secured" access to the resource involving attempting to steal timber, corrupting and threatening the local forest guards, misarranging the tenders and corrupting and threatening the controlling teams. The investment in harvesting and transportation machinery needs to be secured, therefore the corruption is carried out to avoid or prevent the confiscation of the equipment or the interruption of the activity. On the other hand, illegal logging and trade provide work to many people within the chain while supplying a strong household demand, so any attempt to close down the business would have social consequences.

In relation to the social aspects, there are opinions that the current illegal entrepreneurial activities should not simply stopped, but should be converted in legally based activities (Interview 6, 10) in order to create a wood local market, to reduce price volatility and to modernise domestic production [2]. Strategies to cope with illegal logging should consider the underlying drivers of the illegal activities [22] and the fact that market-driven illegal logging expressed an opportunity for rent-seeking activities in the context of deep institutional changes $[40,51,52]$. If the organizational capacity of illegal loggers seems to be high, further analysis is needed to assess the internal complicity of the local communities, as suggested in the diagnostic framework for illegal logging elaborated by Honey-Roses [10].

\subsection{The delineation of the economic property rights in the state forests}

Contrary to what happened in the other former European socialist countries, the legal rights on forestland have not changed over the last decades. Neither nationalization, nor privatizations have affected the ownership structure in Kosovo. The legal owners of the forestland and timber were, as of today, the State (62\%) and the individual private owners (38\%). Important changes have however occurred in the delineation of the economic property rights. Thus, the organisations performing the management and exclusion rights have changed over time.

In the socialist economy within the former Yugoslavian State, the municipalities managed the forest and forestland in State ownership on a territorial basis (municipality area). The management of the whole process of the forestry operations, protection and utilization of State forests was entrusted to the municipalities through local, self-financed forest companies named "Ekonomi Pyjore" ("forest economies" in free English translation) (Interviews 3, 10, 14). The municipality had the right to use the products of the forestland, to self-finance and self-manage the forest company with the right to employ and dismiss the management staff, to operate within the budget or to invest [24], all these economic rights being executed on the State forestland. Additionally, they exercised exclusion rights, notably, guarding against theft in private forests and delivered harvesting permits to forest owners. Many elements of the "Ekonomi Pyjore" were the same as those of socially owned enterprises organized in the whole former Yugoslavia (Interview 14). The fact that the municipalities had all the operational level rights and collective-level rights, except the alienation right (they could not sell forest and forestland that belong to the State) classifies them as "proprietor" according to the frame defined by Schlager and Ostrom [42]. Thus, under the State system prior to 1989 , the rights to manage and use the State forests and forestland and the right to perform exclusion in State and private forests belonged to the municipality within its territory.

At the moment when the political and ethnic conflict arose in 1981, the Yugoslavian State attempted to restrict these large local self-governance possibilities and to centralise the forest management structures, by creating "Sharri", a joint company based in Prishtina, the regional capital of the autonomous province of Kosovo. Most of the "Ekonomi Pyjore" entered this organization, but not all of them (Interview 3, 10, 14), and the process was terminated in 1989 when Kosovo's autonomy was abolished.

Between 1989 and the end of the war (June 1999), all the Kosovo's forests were managed by "Srbija Shume", the public company based in Belgrade that performed also the control of law enforcement in private forests, including the exclusion of unauthorised users (timber thieves). The rights given to "Srbija Shume" in managing the State forests conferred to this agency a proprietor position (Table 3). The centralisation of the management structures in one institution ("Srbija Shume") meant in fact the termination of the municipalities' forest management rights. The centralisation led to the firing of the local forest officials, the reforming or the dismantlement of the wood processing sector attached to the local "forest economies" and perhaps the legal overharvesting of

Table 3 - The repartition of economic rights in Kosovo State forests before the war and during the war.

\begin{tabular}{|c|c|c|}
\hline & Previous to 1989 & Period 1989-1999 \\
\hline & $\begin{array}{c}\text { Proprietor: } \\
\text { municipalities } \\
\text { (through "forest } \\
\text { economies") }\end{array}$ & $\begin{array}{l}\text { Proprietor: } \\
\text { Srbija Shume }\end{array}$ \\
\hline Access & $\mathrm{x}$ & $\mathrm{x}$ \\
\hline Withdrawal & $\mathrm{x}$ & $\mathrm{x}$ \\
\hline Management & $\mathrm{X}$ & $\mathrm{x}$ \\
\hline Exclusion & $\mathrm{X}$ & $\mathrm{X}$ \\
\hline Alienation & No alienation rights & No alienation rights \\
\hline
\end{tabular}


the resource as claimed by the interviewed people (Interview $6,10,12,14)$. Yet this information could not be documented. In this period, the legal basic foundations of property such as reporting of changes and adherence to registered boundaries and to planning regulations seem to have disintegrated [53]. Those interviewed people reported that the records on forest landownership, the maps and the forest management plans had simply vanished from the offices of the "forest economies" (Interviews 3 and 6). As a result of the unrecorded property changes accumulated after the $80 \mathrm{~s}$, the land titles issued after the war recognised de facto landowners as being the legal owners [53].

After the end of the war (June 10, 1999) the territory of Kosovo was placed under the civil authority of the UN Interim Administration Mission in Kosovo (UNMIK) and under the military authority of the Kosovo Force (KFOR). In June 1999, the "forest economies" were re-established by the international administration at the level of the municipalities. However, following the war disorder and the nine years of inactivity the "forest economies" had very limited capacities to perform forest management functions (Interviews 3, 14). In this context, during the war period (1998-1999) and immediate post-war reconstruction (2000-2001), massive illegal logging took place in the whole territory of Kosovo and particularly in State forests (Interviews 7, 11, 30, 32, 42).

The 1987 Law on Forests was still in force by virtue of UNMIK Regulation No. 2000/59, amended by UNMIK Regulation No. 2000/17. In 2000, a new forest management institution was created. The Kosovo Forest Agency (KFA) was established at the central level with six offices in the territory. In addition to insufficient forest staff and a lack of technical means, the KFA was faced with the problem of legitimisation in the eyes of the municipalities, reluctant to recognize it, so far as it was viewed as an institution imposed on them by the international administration, in break with the traditionally decentralised system of forest management (Interviews 3, 7, 14). The establishment of the central forest agency was not without reminding the municipalities of the experience of working under the Serbian forest agency "Srbija Shume" (Interview 4, 7).

When the new Law on forests came into force in 2003, all the rights granted to the municipalities after June 1999 were abolished. The municipalities believed that the government had deprived them of their "ownership" of the forests ([24], Interviews $3,4,7,14,35)$. While de jure municipalities have had no role under the 2003 Law on forests de facto the Ministry of Agriculture and Rural Development has established official cooperation with municipalities and their respective forest departments under a Memorandum of understanding [24]. Table 4 shows the evolution of the municipalities from the position of proprietor (1999-2000) to than an authorised user (after 2003), with no other rights than access and withdrawal. Since 2003, Kosovo Forest Agency (KFA) has performed the exclusion and management rights in State forests, which qualifies it as "proprietor" in State forests. Additionally, KFA performs exclusion rights (protection against timber theft) and law implementation (issuing harvesting permits) in private forests.

In July 2010, within the decentralisation process forecast in the Ahtisaari plan (UN Security Council, 2007) a transfer of public forest authority (worded as "forest competences" in the official document) from KFA towards the municipalities occurred. Thus the municipalities received a full "forest protection competence" (forest guarding against illegal logging, prevention and monitoring of damages, but also prevention of forest pest, diseases and of forest fire) and partly the "forest management competence". The latter one, to be jointly undertaken with the KFA, enables the implementation of forest management plans and of the tendering procedures, the monitoring of harvesting in private forests and the collection of the revenues from the forest activities.

Within this new framework, the municipalities perform the monitoring and guarding services on behalf of the State (competence on forest protection fully transferred), for which they are paid with the $30 \%$ of the revenues collected when performing the competence on forest management. In the eyes of the municipalities, the forest protection is not a "competence" (a right) transferred, but a "duty" (an obligation). As claimed by a municipality representative (Interview $5)$, the municipality is not motivated to do the risky tax collection in the forestry for only $30 \%$ return. Since 2010, both KFA and municipalities play the role of proprietor, with limited and overlapped abilities. New issues such sharing the forestry income, transparency of money flow, control of the forest resource, and organisation of tenders come to aggravate the conflict between KFA and municipalities.

Analysing the distribution of rights in the post-communist context, Weimer [35] identifies four characteristics of welldefined property-rights systems: clarity of allocation, cost of alienation, prevention of trespassing and credibility of persistence. In the peculiar case of Kosovo State owned forests, the allocation of exclusion and management rights is unclear, being divided between one owner (State), two proprietors (KFA and municipalities) and a lot of unauthorised

Table 4 - The repartition of economic rights in post-war Kosovo in State forests.

Period 1999-2000

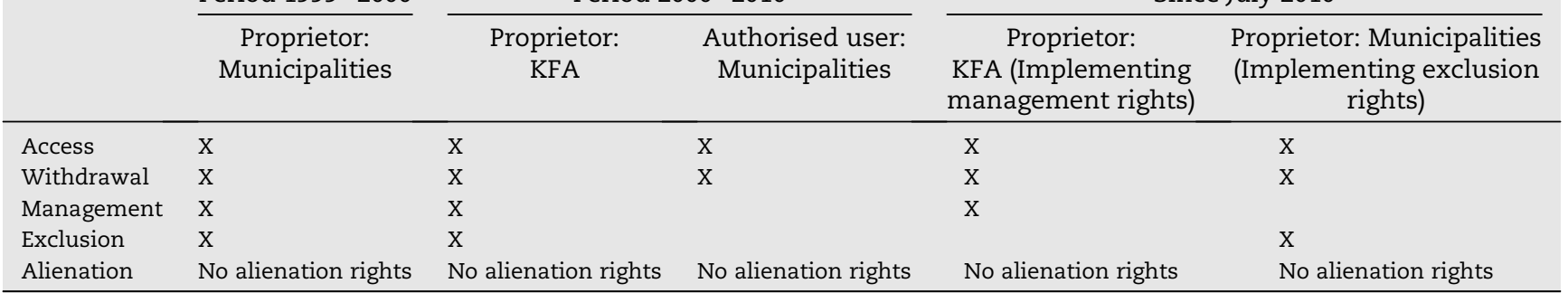

Period 2000-2010 
users (illegal loggers). The existence and the amplitude of timber theft is the argument that the property rights are not well defined [37]. It appears therefore that formalisation of the property rights that is ensuring the legality of the title on the land is not a sufficient condition for economic development and sustainable use of resource, as discussed by Bromley [48] for the developing countries. For instance, the structure of legal rights over the forestland has little relevance to explain the development of Kosovo system of fuelwood production. The results of the study support the idea expressed by Cole and Grossman [47] about the nature of the economic rights, compared with the legal rights. They maintain that if the economic rights are substituted for the legal rights in a society, it is not because "mere doing signify hold a right" [47], but because in the economic conditions of poor rural Kosovo it is "socially acceptable" to do so. The situation is common to some other former socialist countries [11,52,54], particularly in South-Eastern Europe [4], yet here the magnitude of the illegal logging is lower. In fact, in Europe, comparable high incidence of the illegal logging was recorded in only few former socialist countries, and for short periods of time $[11,54]$.

Given the current patterns of illegal logging, fuelwood harvest in war and post-war periods in Kosovo poses the classical open-access problem [55-57]: despite of existing legal title on forestland, in most of the Kosovo forests the fuelwood extraction follows the regime of open-access resource. According to Barzel [37], for different reasons, e.g. the high level of costs associated with enforcement, the fuelwood is left in the "public domain" and then openly accessed.

\subsection{The evolution of the property rights enforcement}

According to those interviewed, illegal logging before the war was at a very low level due to "the efficient enforcement procedures" (Interviews 4, 5, 6) that is convergent with the enforcement situation recorded in socialist countries before the change of the political regime [45,52]. The forest guard was obliged to have an accurate record of timber removal, and he was liable on any missing tree (Interview 4, 12). Thus the level of illegal logging was low, few quantities were stolen at once and in very short time "the forest guard was able to know where, how, who" (Interview 6, 35).

After the war, the law enforcement in general was difficult. Not only were the forest authorities and managers, but also UNMIK police and Courts, faced with particularly difficult challenges in applying criminal procedure [58]. The most significant weaknesses were proper to a post-war context: the relatively rudimentary nature of Courts, insufficient salaries for judicial and law enforcement staff, and the perception that fundamental laws and procedures were imposed on Kosovo people by the international administration without any meaningful local consultation and input [59].

The enforcement system in forestry was progressively built in the last decade being based on three levels of jurisdiction: local forest managers, central forest inspectors and the Courts. The institutional settings in which regulation and policies are enforced is stable since July 2010 (Fig. 1).

In the post-war period (1999-2003) the municipalities were supposed to perform enforcement, but they were lacking basic human and material capacities to do so (Interviews 3, 5, 17, 24). Since 2003, the Kosovo Forest Agency (KFA) has been responsible for deterrence of illegal activities, in coordination with the municipalities since July 2010. The local KFA and municipal forest guards are still in a vulnerable position. They are subject of threats from the illegal loggers, when not involved themselves in illegal activities or paid to keep silent (Interview 7, 15, 32). Also they lack the essential means of enforcement, such as vehicles, mobile phones, or weapons (Interviews 2, 13, 14, 17, 24, 27, 35). The six Kosovo forest inspectors, who serve as the second level jurisdiction, acted within the mandate of the ministry until January 2012 when they were transferred to the KFA so as to facilitate their fieldwork. However, a conflict of interest became an issue in relation to inspectors employed by KFA that would limit their independence in performing law control (Interview 3, 6, 14). Since then, several additional forest inspectors were hired by the KFA.

The law enforcement performed by the forest guards and inspectors against individuals is ineffective when the cases enter the Courts litigation procedures. The forest guard must

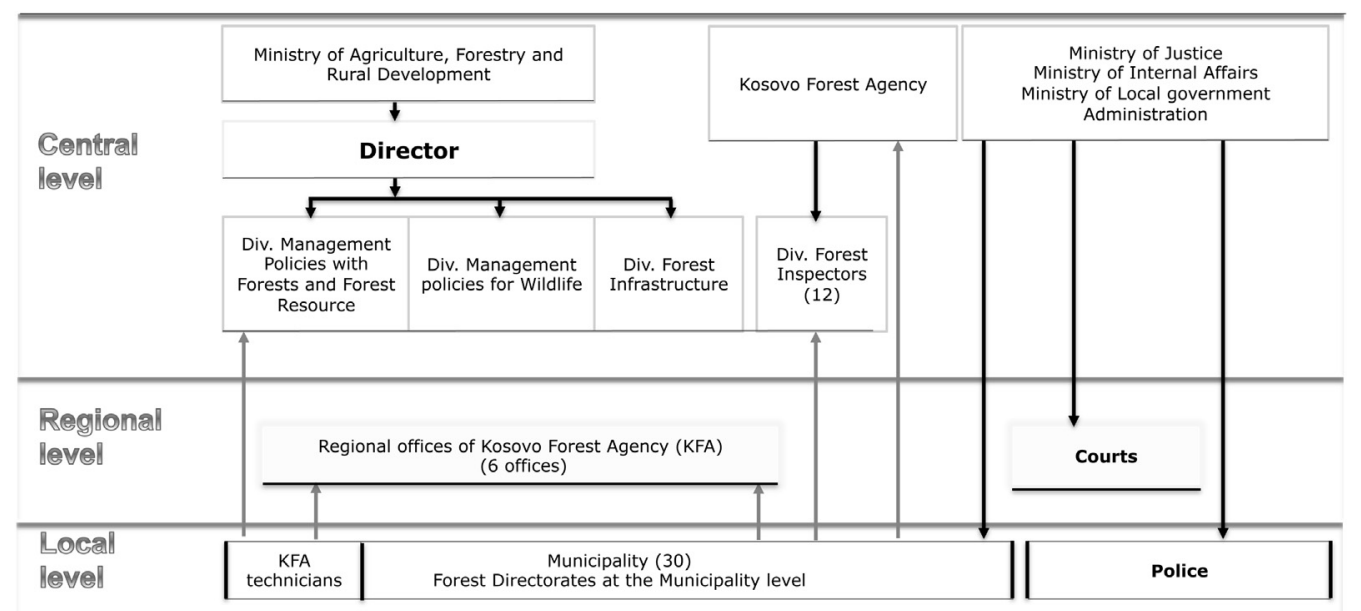

Fig. 1 - Institutional settings of law enforcement in Kosovo forest sector. 
attend each hearing "while the charged individual does not even show up" (Interview 8), but "very few of those charged will be sanctioned, or even they will be released after promising they will not break the law again" (Interview 9). In the end, the cost of the forest guards' attendance to the Courts hearings will be higher than that of the timber theft (Interview 11). Moreover, if the person is released, the damage will remain uncovered, and the KFA will have to pay the judicial procedure costs. Usually, the cases of forest law infringements take three to four years to be completed (Interview 8). Thus, in four years period (2005-2009), only 46 of the 25,745 requests for charges submitted to the Courts were investigated [4]. Of course there are exceptions to the rule, e.g. in Drenas County the Court has been assessed to be operative in a timely fashion in resolving the cases (Interview 12).

Confronted with this situation, some innovative practices have appeared as a simplified and shorter procedure of enforcement. When the KFA representative has identified the illegal logger, the proposed agreement is the recovering on the spot of the damage caused in order to avoid the start of a Court procedure (Interview 9). This practice has been described as easier to implement than long-term Court litigation, yet it has no legal basis and cannot avoid corruption of the controlling staff (Interviews 8, 11, 16).

Thus, in general, in Kosovo, the prevention of trespassing [35] is not ensured due to the ineffective forest guarding and the time-consuming Court procedures. Demsetz [60] suggests that a greater enforcement of the property rights will emerge in response to a greater scarcity of the resource. Nevertheless this scarcity should be perceived as such by the society [61]: by the owners, forest managers, enforcement agencies, resource users and the public at large. Some on-going processes such as the elaboration of the National Action Plan to fight illegal logging might be an indicator that policy-makers start to be concerned with the sustainable supply of the population with fuelwood. Also, the on-going commitment of municipalities in performing forest management may herald some progress. However, the limited number of cases dealt with by the Courts, implying almost invariably the release of the charged persons, suggests that the Kosovo society does not perceive yet that the forest resource is vanishing as shown by the results of the national forest inventory published in 2013 [25].

\section{Conclusion}

The annual illegal fuelwood harvesting in Kosovo, largely overcoming the sustainable extraction rates, represents a market of up to 21.6 million euro and is done mostly by wellorganised groups of individuals, with market-oriented behaviour. Post-war economic conditions and the gap between the fuelwood demand and the legal supply created opportunities to illegal logging activities development. The paper argues that the mismatch on economic property rights arrangements is responsible for this situation. Thus the decades-lasting dispute between the central agency and municipalities in performing exclusion rights on timber extraction definitely weakened the Kosovo system of law enforcement and left the fuelwood production be based on an de facto open-access regime.

\section{Acknowledgements}

LB acknowledges funding from Twinning project Further support to sustainable forestry management in Kosovo, KS09IBEN02, European Commission Liaison Office to Kosovo. All statements of the present paper are the authors' sole responsibility.

\section{R E F E R E N C E S}

[1] Kosovo Statistic Agency Population Census 2011 [internet]. Pristina: kosovo statistic agency [cited 2012 May 28] Available from: http://esk.rks-gov.net/eng/.

[2] International Energy Agency. United Nations Development Programme. Energy in the Western Balkans: the Path to Reform and reconstruction. Paris: IEA Publications; 2008. p. 418.

[3] Ministry of Agriculture. Forestry and rural development. Policy and strategy paper for forestry sector development 2010 - 2020. Pristina: Ministry Agric, Forestry and Rural Development; 2009. p. 35.

[4] Markus-Johansson M, Mesquita B, Nemeth A, Dimovski M, Monnier C, Kiss-Parciu P. Illegal logging in South Eastern Europe regional Report. Szentendre: Reg Environ Cent; 2010 September. p. 136.

[5] Mitchell A. Sustainable forest management for Kosovo. Brux Proj Manag Group, Green Belt Proj Manag Int Serv Group SRL; 2009. p. 147. Funded by European Commission Liaison Office, EuropeAid/122672/D/SER/KOS. Contract No.: CRIS 2008/162109.

[6] Harou A, Hajredini E. Illegal logging in Kosovo: elements of a strategy and action plan. Pristina: United State Agency Int Dev, Kosovo Private Enterprise Program; 2009. p. 60. Contract No.: EEM-I-07-00007-00, TO \#2.

[7] Gibson C, Ostrom E, Williams J. Local enforcement and better forests. World Dev 2005;33(2):273-84.

[8] Tacconi L, editor. Illegal logging: law enforcement, livelihoods and the timber trade; 2007. Earthscan.

[9] Chhatre A, Agrawal A. Forest commons and local enforcement. Proc Natl Acad Sci 2008;105(36):13286-91.

[10] Honey-Roses J. Illegal logging in common property forests. Soc Nat Resour 2009;22(10):916-30.

[11] Bouriaud L. Causes of illegal logging in Central and Eastern Europe. Small-Scale Econ Manage Policy 2005;4(3):269-92.

[12] Kuemmerle T, Chaskovskyy O, Knorn J, Radeloff VC, Kruhlov I, Keeton WS, et al. Forest cover change and illegal logging in the ukrainian carpathians in the transition period from 1988 to 2007. Rem Sens Environ 2009;113(6):1194-207.

[13] Cohen MA. Environmental crime and punishment: legal/ economic theory and empirical evidence on enforcement of federal environmental statutes. J Crim Law Criminol 1992;82(4):1054-108.

[14] Polinsky AM, Shavell S. The economic theory of public enforcement of law. J Econ Lit 2000;38(1):45-76.

[15] Garoupa N, Klerman D. Optimal law enforcement with a rent seeking government. Am Law Econ Rev 2002;4(1):116-40.

[16] Polinsky AM, Shavell S. The theory of public enforcement of law. In: Polinsky AM, Shavell S, editors. Handbook of law and economics. North-Holland; 2007. pp. 403-54.

[17] Kissling-Näf I, Bisang K. Rethinking recent changes of forest regimes in Europe through property-rights theory and policy analysis. Policy Econ 2001;3:99-111.

[18] Mustafa B, Zeqir V, Avni H, Zenel K. Management status of protected areas in Kosovo. Procedia Soc Behav Sci 2011;19:651-4. 
[19] Mustafa B. Basic characteristic of flora and vegetation of Kosovo and danger of their disappearance. Albanian J Nat Tech Sci 1998;5:115-21.

[20] Zeqir V, Mustafa B, Hajdari A, Krasniqi Z. Biodiversity conservation status in the Republic of Kosovo with focus on biodiversity centres. J Environ Biol 2012;33:307-10.

[21] World Bank Europe and Central Asia Region Sustainable Development Department. Integrating environment into agriculture and forestry progress and prospects in Eastern Europe and Central Asia. Volume II Kosovo. World Bank; 2007 November. p. 15.

[22] Contreras A, Peter E, editors. Best practices for improving law compliance in the forest sector. Rome: Food and Agriculture Organisation of the United Nations, International Tropical Timber Organisation; 2005. p. 132. FAO Forestry Paper No.: 145.

[23] Amariei L. Kosovo cluster and business support project: evaluation of forest management in Kosovo's publicly owned forests. Pristina: United States Agency Int Dev, Chemonics International Inc; 2007. p. 51. Contract No.: AFP-I-00-0300030-00, TO \#800.

[24] RIINVEST Institute for Development Research. Kosovo cluster and business support project: forest industry challenges of development and balance use. Pristina: United States Agency Int Dev, Chemonics International Inc; 2008. p. 69. Contract No.: AFP-I-00-03-00030-00, TO \#800.

[25] Tomter SM, Bergsaker E, Muja I, Dale T, Kolstad J. Kosovo national Forest inventory 2012. Pristina: Kosovo Ministry of Agriculture, Forestry and Rural Development, Nor For Group; 2013. p. 58.

[26] Buchenrieder MI. Analysis of renewable energy and its impact on rural development in Kosovo. Deliverable D2.2 of the FP7 project AgriPolicy Enlargement Network for Agripolicy Analysis; 2009 November. p. 25.

[27] Bowen BH, Myers JA, Nixha A. Kosova's household energy efficiency and fuel supplies. Int J Energ Se Manag 2011;5(4):545-63.

[28] Opalić T, Šafar L. Study and analysis of innovative financing for sustainable Forest management in the Southwest Balkan: study on firewood and other wood biomass use by population, household Survey. Tirana: REGEA - NW Croatia regional Energy Agency, connecting natural values and people; 2013. Contract No.: 7160594. Financed by World-Bank PROFOR

[29] Bowen BH, Myers JA, Myderrizi A, Hasaj B, Halili B. Kosovo household Energy consumption facts and Figures. Pristina: AUK-RIT Center for Energy \& Natural Resources, American University in Kosovo, Rochester Institute of Technology; 2013 March. p. 82. Financed by World Bank, Rockefeller Brothers Fund, Norwegian Institute for nature research.

[30] Hajredini E, Kampen P. Study and analysis of innovative financing for sustainable forest management in the Southwest Balkan: analysis on production, current and potential for wood biomass, from public and private forests and agricultural land in Kosovo. Tirana: NRS Consultancy, Connecting Natural Values and People; 2013. Contract No.: 7160594. Financed by World-Bank PROFOR.

[31] Alchian A, Demsetz H. The property right paradigm. J Econ Hist 1973;33:17-27.

[32] Alston LJ, Mueller B. Property rights and the state. In: Menard C, Shirley M, editors. Handbook of new institutional economics. Springer; 2005. pp. 573-90.

[33] Irimie DL, Essmann HF. Forest property rights in the frame of public policies and societal change. Policy Econ 2009:11:95-101.

[34] Fréchette A, Lewis N. Pushing the boundaries of conventional forest policy research: analyzing institutional change at multiple levels. Policy Econ 2011;13(7):582-9.
[35] Weimer D. The political economy of property rights. In: Weimer D, editor. The political economy of property rights: institutional change and credibility in the reform of centrally planned economies. Cambridge: Press Syndicate of the University of Cambridge; 1997.

[36] Lueck D, Miceli TJ. Property law. In: Polinsky AM, Shavell S, editors. Handbook of law and economics. North-Holland; 2007. pp. 183-257.

[37] Barzel Y. Economic analysis of property rights. 2nd ed. Cambridge: Cambridge University Press; 1997.

[38] Bouriaud L. Economic and policy analysis of property rights allocation in central and eastern European countries [dissertation]. Nancy: Ecole Nationale du Genie Rural des Eaux et de Foret; 2002.

[39] Bouriaud L, Schmithüsen F. Allocation of property rights on forests through ownership reform and forest policies in central and eastern European countries. Schweiz Z Forstwes 2005;156(8):297-305.

[40] Nichiforel L, Schanz H. Property rights distribution and entrepreneurial rent-seeking in Romanian forestry: a perspective of private forest owners. Eur J For Res 2011;130(3):369-81.

[41] Foss K, Foss NJ. Assets, attributes and ownership. Int J Econ Bus 2001;8:19-37.

[42] Schlager CE, Ostrom E. Property-rights regimes and natural resources: a conceptual analysis. Land Econ 1992;68(3):249-62.

[43] Umbeck J. Might makes right: a theory of the formation and initial distribution of property rights. Econ Inq 1981;19:38-59.

[44] Bromley DW Environment and Economy. Property rights and public policy. Oxford: Blackwell Publishers; 1991. p. 247.

[45] World Bank. Forest institutions in transition: experiences and lessons from Eastern Europe. Wash D.C PROFOR A. T World Bank; 2005 February. p. 96.

[46] Grafton RQ. Governance of the commons: a role for the State? Land Econ 2000;76(4):504-17.

[47] Cole DH, Grossman PZ. The meaning of property rights: law versus economics? Land Econ 2002;78(3):317-30.

[48] Bromley DW. Formalising property relations in the developing world: the wrong prescription for the wrong malady. Land Use Pol 2008;26:20-7.

[49] de Singly F, Blanchet A, Gotman A, Kaufmann J-C. Ancheta și metodele ei: chestionarul, interviul de producere a datelor, interviul comprehensive [Methods for inquires: questionnaires, data interviews and comprehensive interviews]. Bucuresti: Polirom; 1998.

[50] Miles M, Huberman M. Qual data anal, an expanded sourcebook. 2nd ed. London - Thousand Oaks - New Delhi: SAGE Publication; 1994.

[51] Edwards S. Rent-seeking and property rights formation in the U.S. Atlantic sea scallop fishery. Mar Resour Econ 2002;6:263-75.

[52] Stahl J. The rents of illegal logging: the mechanisms behind the rush on forest resources in southeast Albania. Conserv Soc 2010;8(2):140-50.

[53] Meha M, Haldrup NO, Frrokaj A, Gashi I, Ramadani A. Land consolidation and rural development in kosovo [Internet]. Food and Agriculture Organisation of the United Nations regional workshop on EU rural development Programme; 2007 June 25-27; Prague; Czech Republic. [cited 2012 Sept 20]. Available from: http://www.fao.org/fileadmin/user_upload/ Europe/documents/Events_2007/Land2007/Kosovo.pdf.

[54] Pop I. In padure (se fura) ca-n codru! O analiza a mecanismelor de combatere si prevenire a ilegalitatilor silvice in Romania [In the forest one stills like in the woods. analysis Mech Prev illegal logging Romania]. Bucuresti: Centrul Pentru Politici Durabile ECOPOLIS; 2012. p. 48. 
[55] Dietz T, Ostrom E, Stern PC. The struggle to govern the commons. Science 2003;302(5652):1907-12.

[56] Gardner R, Ostrom E, Walker JM. The nature of common-pool resource problems. Ration Soc 1990;2(3):335-8.

[57] Ostrom E, Gardner R, Walker J. Rules, games and common pool resources. Ann Arbor: University of Michigan Press; 1994.

[58] Brand M. The development of Kosovo institutions and the transition of authority from UNMIK to local self-government. Geneva: Centre for Applied Studies in International Negotiations; 2003. p. 54
[59] Spector BI, Winbourne S, Beck LD. Corruption in kosovo: observations and implications for USAID. Washington DC: Management Systems International, United States Agency for International Development; 2003 July. p. 44.

[60] Demsetz H. Toward a theory of property rights. Am Econ Rev 1967;57(2):347-59.

[61] Bromley DW. Property regimes in economic development: lessons and policy implications. In: Lutz E, editor. Agriculture and the environment: perspectives on sustainable rural development (a World Bank symposium). Wash D.C; 1998. pp. 83-91. 